\title{
Determinants of Working Capital Investment: A Study of Malaysian Public Listed Firms
}

\author{
Shaista Wasiuzzaman ${ }^{1} \&$ Veeri Chettiar Arumugam ${ }^{1}$
}

The paper examines the determinants of the level of investment in net operating working capital by firms in Malaysia. Data from 192 companies spanning a period of 8 years (20002007) are analysed using the OLS regression technique for this purpose. The study finds that in times of economic expansion, younger and smaller firms with less tangible assets, low leverage, high immediate sales growth, high operating cash flows, less volatile revenues and low levels of asymmetric information are likely to have the highest investments in operating working capital. Board characteristics, namely size and the independence of the board, are not found to have any significant influence on the working capital investment of firms.

Keywords: Working capital investment; pecking order theory; asymmetric information; board characteristics.

JEL Code: M40

\footnotetext{
${ }^{1}$ Multimedia University, Malaysia

Email: shaista@mmu.edu.my
} 


\section{Introduction}

The liquidity problems faced by huge corporations, especially during the global financial crisis of 2008, raised awareness among firms to unlock the valuable cash that is tied up in the working capital cycle. A firm's net working capital position influences its ability to obtain debt financing as many loan agreements with financial institutions require a firm to maintain a minimum net working capital position (McGuigan et al. 2012).

REL/CFO Asia Magazine (25 September 2007, p1) reports in their article that in 2006, Asia’s 725 largest companies significantly improved their working capital performance (by cutting working capital by 2.8\%), releasing $\$ 15$ billion largely through better bill collection and improved inventory management. But \$535 billion was still unnecessarily tied up in working capital. Despite the overall improvement in Asia, Malaysia was one of the countries where overall working capital performance degraded (with days' working capital increasing by $27.5 \%$ compared to the previous year). The situation did not improve in 2007 where 850 of the Asia-Pacific region's top companies had $\$ 833$ billion in total working capital which was not put to productive use. Ernst \& Young (2011) reports that compared to 2009, in 2010, most companies reported improvement in their working capital management although the improvements were made more in the area of payables compared to receivables and inventories. Yet the companies surveyed still had billions tied up in working capital, representing a large proportion of their working capital scope.

Knowing that working capital investment should be kept to as minimum as possible, why do companies still have billions tied up in working capital? According to Vijayakumar and Venkatachalam (1996, p647), "the developing economies are generally faced with the problem of inefficient utilisation of resources available to them" and while fixed assets and working capital are both "contributors to the total capital of the developing country", working capital makes utilisation of the production capacity generated by the fixed assets possible.

Could the reason for inefficient utilisation be related to the features of the firms, to macroeconomic or other factors? Shyam-Sunder and Myers (1999) include the net increase in working capital as one of the factors affecting the funds flow deficit which in turn affects the amount of debt issued - or retired. Prior studies have shown that leverage is a significant contributor to a firm's choice on the level of its working capital investment (such as Ban osCaballero, Garc1'a-Teruel \& Martı'nez-Solano 2010a; Chiou, Cheng \& Wu 2006; Kargar \& Blumenthal 2004). There are also studies which highlight other firm-specific factors affecting the efficient working capital management of a firm, such as its growth, profitability, size/capital market access, asset tangibility, revenue volatility, age, operating cash flow, level of asymmetric information and even board characteristics.

Hence, the objective of this study is to determine the factors influencing a firm's decision with regards to the size of its investment in net operating working capital. An investigation into the factors affecting net investment in working capital should integrate the individual components (Hill, Kelly \& Highfield 2010). The variable should be able to account for the joint effects of the three components of working capital. Working capital investment is measured with the net operating working capital.

To achieve the objective, the Ordinary Least Squares (OLS) regression method is used on financial data of 192 firms from year 2000 to 2007. The results of the study show that firm-specific factors such as leverage, growth, asset tangibility, age, firm size, profitability, operating cash flows, revenue volatility and asymmetric information significantly influence the investment in operating working capital. However, board characteristics do not have significant influences on working capital investment. Favourable economic conditions result in firms having higher investments in working capital. 
The rest of the paper is organised as follows. In the next section some of the theories related to working capital investment are discussed, followed by a section where the relationships between working capital investment and various variables are discussed by referring to previous studies on working capital. From these studies, the testable hypotheses are developed and the variable measurements are presented. In the fourth section, the sampling method and research methods are presented. Results of the analysis are reported and discussed in the fifth section, followed by the conclusion in the final section.

\section{Theoretical Resources}

In an ideal world, net working capital is always zero but in practice, this is not the case as the current assets of a firm are unlikely to ever drop to zero (Ross et al. 2008). Each component of working capital has its own costs and benefits. For instance, holding inventory helps managers to minimise the risk of 'stock-outs' and to deal with seasonal sales but carrying costs will be high. However, having too little inventory could mean running short and losing sales and customer goodwill and may result in disruption in production (Brigham \& Daves 2004). With respect to receivables, Salek (2005) lists two conflicting objectives where tradeoffs will be required in order to achieve efficient receivables management. Firstly, in order to boost sales, the criteria for allowing credit needs loosening up but this can result in high bad debt losses. However, tightening it would reduce receivables and bad debt losses but result in lower sales. The second conflicting objective is "to achieve strong receivables management results and provide excellent financial service to customers versus minimising the cost of the function" (Salek 2005, p7). Finally, firms may be able to get discounts for early payment of their trade credit (Banos-Caballero et al. 2010a) but as pointed out by Berk DeMarzo \& Harford (2009), a firm should only choose to borrow using accounts payables if it is the cheapest source of funding, i.e. the free component should always be used but the costly component should be first analysed with respect to its cost and compared with the costs of other sources of funds. Thus, the efficient management of working capital requires the efficient management of these components.

In an imperfect world, the problems of asymmetric information and agency costs influence the financing choices of a firm. Of the capital structure theories, Myers' (1984) pecking order theory deals with the role of asymmetric information in determining the amount of debt and equity a firm will issue. Firms should finance investments first with internal funds, then with safe debt, followed by risky debt and finally with equity to reduce the adverse signals that may be emitted. The implication of the pecking order theory is that firms do not have a target debt-equity ratio as they choose their leverage ratio based on their financing needs. This theory also implies that firms do not have target cash balances but cash is actually used as a buffer between retained earnings and investment needs (Ferreira \& Vilela 2004). This also means that when a firm increases its internal funds, its leverage falls. As a firm continues to maintain a surplus of internal funds for the purpose of reducing adverse selection costs, it will accumulate excess cash which it will use to pay off its debt when due. As for a firm which does not have a constrained investment policy, it simply uses cash flow to increase cash (Opler et al. 1999). Working capital is a readily available internal source of financing which can thus act as an alternate source of financing to external capital, especially for the purpose of fixed-investment smoothing in order to maintain a stable fixedinvestment path. External funds can be very costly due to floatation costs and the problem of asymmetric information, especially for financially constrained firms (Fazzarri \& Petersen 1993). 
A higher stock in working capital, which will have lower marginal valuation to the firm (Fazzari \& Petersen 1993), allows managers to pursue their positive net present value projects without having to worry about having to issue undervalued securities. The argument of the pecking order theory implies that there is a very strong relationship between investment in working capital and information asymmetry. Due to this, firms with different characteristics, such as growth opportunities, size, asset tangibility etc., would result in different investment policies in working capital depending on the roles played by these characteristics in aggravating and/or reducing the problem of asymmetric information and the costs associated with the level of asymmetric information.

Aside from the pecking order theory, the free cash flow hypothesis by Jensen (1986) is another theory that may have implications for the level of working capital investments chosen by a firm. It emphasises the agency costs of free cash flow. According to this theory, managers would accumulate cash in order to increase the amount of assets they can control and to gain discretionary power over their firm's investment decisions (Ferreira \& Vilela 2004). Thus managers prefer to hold more cash and high levels of investment in working capital to reduce the firm's investment risk to lessen the probability of bankruptcy and place too much importance on the precautionary motive of holding cash (Opler et al. 1999). Accumulation of cash and having a large pool of liquidity available when needed through the working capital cycle reduces the pressure on managers to perform well and allows them to choose projects that make them happy (usually for empire building) but may not necessarily keep shareholders happy. Management would rather keep resources and tend to waste them on inefficient investments than pay out to shareholders (Drobetz, Gruninger, \& Hirschvogl 2010). They are also not subjected to monitoring of the capital markets (Pinkowitz 2000) when financing new projects internally since they do not have to obtain new capital externally, which can also be very expensive (Jensen 1986). A disciplining mechanism for managers would then be to increase the level of debt in the firm to reduce the free cash flow available, and hence the agency costs related to free cash flows, especially in firms with large cash flows and low growth opportunities.

Based on this theory, there are several implications. Firms with greater agency problems tend to accumulate cash and have very flexible working capital policies in order to have sufficient liquidity even if they do not have good investment opportunities. Cash holdings increase mainly in firms with high free cash flows generated (weak growth opportunities and low Tobin's q) and entrenched management which does not face much pressure to pay out the accumulated cash holdings to shareholders in the form of dividends (Bates, Kahle \& Stulz 2009). Such a firm may actually be lax in collecting on its receivables and overinvest in inventories as the pressure is not there to release the cash and make better use of it. Thus, as Jensen (1986) argues these firms are more likely to be takeover targets. Ironically, entrenched and inefficient managers may prefer to keep high levels of liquidity to counter takeover attempts. Excess cash holdings and too high investment in net operating working capital could indicate bad management quality if judged by the investment opportunities of the firm. Opler et al. (1999) point out that firms could be holding too much cash in order to defend themselves from unwanted takeover attempts and that these firms may be more difficult to value because of the liquidity (Pinkowitz 2000). Similarly, these firms could have high levels of investments in working capital. Hence, Jensen's (1986) free cash flow theory indicates the possible influence of agency costs on the working capital investment policy of a firm. 


\section{Determinants of Working Capital and Testable Hypotheses}

The pecking order theory and the free cash flow theory imply the role of asymmetric information and agency costs in determining the optimal working capital investment policies of firms, both directly and indirectly. Hence, previous literatures are referred to in order to understand the role of various firm characteristics in reducing or aggravating these two issues with respect to the investment in working capital.

\section{Leverage}

Chiou et al. (2006) argue that based on the pecking order theory, a firm would try to finance its long-term investments with internal financing first to reduce monitoring and limitations by shareholders and also to reduce issue costs. Hence, a firm with more debt will mean that it has less internal financing and that there could be less capital available for daily operations. This would create an environment of caution to avoid further aggravation of the funds shortage problem, resulting in optimal efficiency of working capital. External financing being more costly than internal financing (due to higher premium) would mean that a firm with a rising debt ratio would pay more attention to their working capital to avoid capital, which can be used for more profitable investment opportunities, being stuck in the operating cycle (Nazir \& Afza 2009). Also, since the return from working capital is low, investing highercost funds in the working capital cycle would not seem to be a good idea (Banos-Caballero et al. 2010a). This negative relationship is confirmed by Raheman and Nasr (2007), Zariyawati et al. (2009), Mathuva (2009), Zariyawati et al. (2010) and Erasmus (2010) for different countries.

Hence a significant negative relationship is expected to exist between the working capital investment of a firm and its amount of leverage (LEV), which is measured as the value of a firm's long-term debt, which includes the short-term portion of the firm's long term borrowing, divided by the sum of the value of the firm's long-term debt and its market capitalisation. The alternative hypothesis is:

Alternative Hypothesis (H1a): Leverage has a significant negative influence on the level of working capital investment of a firm.

\section{Immediate Growth Opportunities}

One of the implications of the pecking order theory is that a firm which anticipates more growth opportunities will need more capital in the future and so will need more internal financing. In anticipation of this, it will then increase its cash holdings and short-term investment. Anticipation of high sales growth could result in firms stocking up on inventory which could outweigh the effect on trade credit (Moussawi et al. 2006). The positive effect of growth on inventory is confirmed by Blazenko and Vandezande (2003). Appuhami (2008), Banos-Caballero et al. (2010a), Chiou et al. (2006), Hill et al. (2010) and Nazir and Afza (2009) find a positive relationship between working capital and sales growth.

However, a firm with high growth rate will keep operating-related working capital and liabilities at relatively low levels and hence a negative relationship between growth and the working capital requirement of a firm is also expected (Chiou et al. 2006). Hill et al. (2010) contend that based on previous literature the relationship between sales growth and trade capital is an inverse one. However, they point out that the relationship between the other component of working capital, which is inventory, and sales growth is not clear from 
previous literature. Erasmus (2010), Zariyawati et al. (2009) and Zariyawati et al. (2010) demonstrate this negative relationship between working capital and growth rate of a firm.

Revenue growth (GROWTH) is used as a measure of immediate investment/growth opportunities, as specified by D’Mello, Krishnaswami \& Larkin (2008). Revenue for year t is divided by that of year t-1. The natural log value of the result is then calculated to find the revenue growth rate. Based on the arguments above, there is no clear consensus on the relationship between growth and working capital investment. The alternative hypothesis is thus:

Alternative Hypothesis (H2a): Growth opportunity has a significant influence on the level of working capital investment of a firm.

\section{Asymmetric Information}

For less transparent firms, given the level of asymmetric information, the long-term projects and cash flows of such firms would be more difficult to value. The market would expect a higher premium for these firms, i.e. it would be more expensive for the firms to obtain financing externally (Hill et al. 2010). Hence, these firms would follow the pecking order theory and use internal resources first. Banos-Caballero Garc1'a-Teruel \& Martı'nez-Solano (2010b) reason that according to Myers (1977), firms with more growth opportunities have higher information asymmetry and also more agency conflicts since the valuation of these firms is dependent mostly on the future growth prospects. Consequently, in order to have as many internal resources as possible, these firms would need to have lower investments in working capital.

Hill et al. (2010) measure asymmetric information as the book-to-market ratio (MTB), especially in connection with the long-term investment opportunities of a firm. The marketto-book ratio is measured as the book value of total assets minus the book value of equity, which results in the book value of liabilities, plus the market value of equity. This value is then divided by the book value of the assets. From the arguments above, the level of asymmetric information is expected to have a negative impact on working capital management. Accordingly, the alternative hypothesis is:

Alternative Hypothesis (H3a): The level of asymmetric information has a significant negative influence on the level of working capital investment of a firm.

\section{Size or Capital Market Access}

Hill et al. (2010) equate capital market access to size since according to Brennan and Hughes (1991) larger firms face increased monitoring by analysts and so there is less information asymmetry, allowing them easier access to capital compared to smaller firms. They argue that since there is easier access to external capital, less information asymmetry and fewer borrowing constraints, larger firms can afford to have relaxed receivables and inventories policies. Larger firms having higher sales levels would require larger investments in working capital (Moussawi et al. 2006). These firms tend to enjoy more growth opportunities (Chiou et al. 2006). Also, since size aggravates the agency problem between shareholders and creditors and asymmetric information is more severe due to the lack of public information, a positive relationship is expected (Banos-Caballero et al. 2010a).

On the other hand, larger firms may have greater bargaining power with suppliers and customers and so a negative relationship is also possible (Banos-Caballero et al. 2010a; Moussawi et al. 2006). Further, large firms tend to be more diversified and fail less often as 
compared to smaller firms. Moss and Stein (1993) show that larger firms actually are able to manage their cash conversion cycles better. This is further confirmed by Chiou et al. (2006), where they also reason that because larger firms have easy access to capital, cash would be kept at a minimum and there would then be a negative relationship between working capital management and size. Nazir and Afza (2008) and Zariyawati et al. (2010) also find this negative relationship in their study.

The impact of size (SIZE), measured by the natural log of total assets, on working capital investment is mixed. This leads to the next alternative hypothesis:

Alternative Hypothesis (H4a): Size has a significant influence on the level of working capital investment of a firm.

\section{Asset Tangibility}

Moussawi et al. (2006) argue that inventory and receivable problems of an automobile parts manufacturer, for example, are most probably going to be different from others because of the tangibility of their assets. Banos-Caballero et al. (2010a) point out two different points of view for the relationship between asset tangibility and working capital investment. On the one hand, a negative relationship is expected because the investment in fixed assets competes with the investment in working capital for the limited funds available. On the other hand, from the point of view of asymmetric information and agency problems, firms with more intangible assets will have higher asymmetric information and agency problems due to difficulty in valuation of intangible assets. So it is likely that these firms will have higher working capital investment (Banos-Caballero et al. 2010a).

Asset tangibility (TANG) is measured by the ratio of a firm's tangible fixed assets to the value of its total assets. The arguments by Banos-Caballero et al. (2010a) mean that the effect of tangibility on working capital investment is not clear. Hence, the alternative hypothesis is:

Alternative Hypothesis (H5a): Asset tangibility has a significant influence on the level of working capital investment of a firm.

\section{Revenue Volatility}

Hill et al. (2010) find mixed results for the relationship between working capital requirement and sales volatility based on past literature. They argue that with higher sales volatility, or high deviations in demand, coming up with the optimal level of inventory may be difficult and so to be on the safe side, firms could increase inventory levels. However, it is not necessary for firms to increase inventory levels as some firms with cost advantages in receivables financing might want to extend additional credit to customers in order to avoid the build-up of inventory (Emery 1987). Hill et al. also point out that studies by Deloof and Jegers (1996) and Ng, Smith and Smith (1999) find no evidence of any relationship existing between receivables and sales volatility. On payables, they argue that since firms with higher sales volatility find it difficult to predict revenues, they tend to rely on payables for better cash flow.

The volatility in total revenue (REVVOL) is calculated as the standard deviation of the annual revenues over a rolling five-year period prior to each of the sample years, as was measured by Hill et al. (2010). The value is then divided by the average revenue over the same five-year period. Only if the firm had at least three observations during the previous 
three year periods, could the firm be included in the analysis. Revenue data from 1996 to 1999 is used to calculate the standard deviation of revenue (or revenue volatility) for year 2000. The overall effect of revenue volatility on operating working capital is mixed mainly due to the uncertain results in each of its components. The alternative hypothesis is thus:

Alternative Hypothesis (H6a): Revenue volatility has a significant influence on the level of working capital investment of a firm.

Age

Chiou et al. (2006) use age of a firm as a representative variable representing the growth opportunities of a firm. Young firms would have higher growth rates, i.e. have better growth opportunities. Over time, the growth rates become stable, indicating that older firms will have less growth opportunities and so will have more capital retained (Chiou et al. 2006). As a firm grows older, its relationship with customers and suppliers and its experience in managing its inventory would make it possible to invest less in working capital. So, there is a negative relation between age and growth opportunities. Because the effect of growth on working capital management of a firm has mixed results and the relationship between growth and age is an inverse one, it is expected that there is a relationship between age and the working capital requirement of a firm but the relationship can be both ways. However, the effects of growth and age on working capital management should be in the opposite direction.

Due to the wide variations in the age of the firms in the sample of this study, age (AGE) is measured as the age of the firm since the date of its incorporation. The effect of age on working capital investment is not clear and the alternative hypothesis is:

Alternative Hypothesis (H7a): Age has a significant influence on the level of working capital investment of a firm.

\section{Profitability}

In almost all studies on the impact of liquidity on profitability, a highly significant negative relationship was found (Beaumont \& Begemann 1997; Bhattacharyya \& Raghavachari 1977; Deloof 2003; Garcia-Teruel \& Martinez-Solano 2007; Ghosh \& Maji 2004; Narware 2004; Shin \& Soenen 1998; Soenen, 1993; Talha, Christopher \& Kamalavalli 2010). Few looked at the opposite relationship however. Even when this relationship is considered, Chiou et al. (2006) argue that since it was easy for profitable firms to obtain funding and cash would be kept at a minimum, a negative relationship is expected between working capital management and firm performance/profitability. The results of Banos-Caballero et al. (2010a) confirm this.

However, Nazir and Afza (2008) reason that since highly profitable firms have the cash to invest in investment activities, they would not be concerned with efficient management of working capital. Hence, there should be a positive relationship between profitability and working capital requirement. The same relationship was expected by Hill et al. (2010, p785), who argue that "the dollar value of a good in terms of receivables generally exceeds the dollar value of a good in payables...”. Both studies confirm this relationship, even though Nazir and Afza (2008) and Hill et al. (2010) measure profitability differently.

The effect of profitability (PROFIT), measured by the return on common equity (ROCE), on working capital investment can be either positive or negative. The ROCE is calculated as the net income before appropriations divided by the value of common equity of the firm. Accordingly, the alternative hypothesis is: 
Alternative Hypothesis (H8a): Profitability has a significant influence on the level of working capital investment of a firm.

\section{Operating Cash Flow}

Chiou et al. (2006) argue that two types of relationships exist between operating cash flow and investment in working capital. Investment in working capital will be positively affected by fluctuations in operating cash flow due to the increase in cash holdings and short-term investments. High operating cash flows allow a company to pursue a conservative operating working capital strategy but negative operating cash flow firms will need to finance their working capital requirement through other sources (Hill et al. 2010). Banos-Caballero et al. (2010a) cite the findings of Fazzari and Petersen (1993), which suggest that firms with higher cash flows have greater capacity to generate internal cash flows and so would have higher levels of current assets probably due to the lower costs of funds invested in the working capital.

On the other hand, higher cash flows result in leniency in terms of pay operationrelated liabilities and accelerated collection of accounts receivables, thus resulting in lower working capital requirements (Chiou et al. 2006). This result is supported by Appuhami (2008) who finds that companies tend to reduce investment in working capital with an increase in operating cash flow.

Operating cash flow (OCF) is measured as the earnings before interest and taxes (EBIT) plus depreciation and amortisation minus interest expenses, tax and common dividends. It is then scaled by revenue at time $\mathrm{t}-1$. The effect of operating cash flow on working capital investment is hence non-directional. The alternative hypothesis is:

Alternative Hypothesis (H9a): Operating cash flow has a significant influence on the level of working capital investment of a firm.

\section{Board Characteristics - Board Size}

Not much research has been carried out on the effect of board characteristics on the working capital management of firms. Moussawi et al. (2006) look at the effect of board size (as measured by the number of directors) and the proportion of outsiders on the board. They contend that larger boards will result in problems in monitoring management and so, working capital requirement will be high. Zariywati et al. (2010) expected this relationship too but find a negative relationship in their results.

It is thus expected that board size (BSIZE), which is the number of directors serving on the boards, will affect working capital investment positively, resulting in the following alternative hypothesis:

Alternative Hypothesis (H10a): Board size has a significant positive influence on the level of working capital investment of a firm.

\section{Board Characteristics - Board Independence}

Generally it is expected that if the board is more independent, there will be more stringent monitoring of management and this will result in lower cash conversion cycles. This result is also confirmed by Zariyawati et al. (2010). 
However, there are a growing number of studies on the ineffectiveness of independent boards in monitoring managers as the exact process of election of independent directors is at most times vague. Managers could be choosing the independent directors while still fulfilling the corporate governance requirements. In fact, some studies have labelled the role of independent directors as 'rubber stamps' (Cornforth 2002) or even 'cheerleaders' (Cohen, Frazzini \& Malloy 2008) in support of management's decisions. This may result in increased managerial optimism and hence, ineffective management may result in higher cash conversion cycles.

Board independence (BINDEP) is measured as the proportion of independent directors serving on the board. It is not clear exactly how board independence will affect working capital investment. Hence, the final alternative hypothesis is:

Alternative Hypothesis (H11a): Board independence has a significant influence on the level of working capital investment of a firm.

\section{Economic Condition}

During periods of recession, it is expected that since the expansion of a company may not run as smoothly as possible and problems may occur in collecting receivables and selling off inventory, this may result in a higher net volume of working capital requirements (Chiou et al. 2006). Hence, working capital investment may be kept high in order to ensure smooth daily operations. In their study on Malaysia, using GDP growth, Zariyawati et al. (2010) confirm that Malaysian firms' investment in net operating working capital increased with better economic conditions. However, Lamberson (1995) finds that small firms seem to act in a different manner compared to larger firms when it comes to economic conditions. In fact, he finds that working capital investment of small firms is relatively stable over time.

From another point of view, it can be said that during times of economic boom, when financing is abundant, firms would not be very concerned about the level of working capital or the cash stuck in the working capital cycle. However, during recession, when there are attempts to squeeze out cash from wherever possible, firms try to reduce their working capital cycle (Banos-Caballero et al. 2010a).

The hypothesis on the effect of economic conditions (ECONCON), measured by the annual change in the real GDP, on working capital investment is non-directional and states:

Alternative Hypothesis (H12a): The economic condition has a significant influence on the level of working capital investment of a firm.

\section{Data and Methodology}

\section{Data and Sample}

Data are collected from three databases; the Datastream International Database, ISI Emerging Markets Database and Research Insight Database provided by Compustat, in order to obtain maximum number of firms for the analysis. The annual reports of the companies are also referred to for information on the board characteristics of the firms. GDP data are obtained from the International Monetary Fund (IMF) database.

Companies from all sectors of the Main Market of the Bursa Malaysia, which have complete data from 1996 to 2007, are considered, except for the finance and regulated sectors. The data is obtained from 1996 in order to calculate revenue volatility but the 
analysis is carried out only from year 2000 onwards. Some sectors such as the technology and mining sectors have less than 20 companies listed at the time of collection and after considering the criteria of having complete data from 1996 to 2007, only less than 10 companies can be considered; thus these sectors are also excluded. From the remaining sectors, some companies have missing data, which is sometimes due to a change of reporting or halt in operations. There are also extreme values, which result in extreme kurtosis and skewness. The extreme values are identified through the use of boxplots and normal probability plots. Hence companies with missing and/or extreme datasets are excluded from the analysis. The remaining balanced panel dataset of 192 companies is analysed over 8 years, from year 2000 to 2007, resulting in 1536 firm-year observations. Finally, the data are then winsorised at $1 \%$ and $99 \%$ level.

\section{Methodology}

The effect of the independent variables on the level of working capital investment is expected to be linear and can be analysed through the following model:

$$
\begin{aligned}
& \text { NWC }_{i t}=\beta_{0}+\beta_{1} \text { LEV }_{\text {it- } 1}+\beta_{2} \text { GROWTH }_{\text {it- } 1}+\beta_{3} \text { MTB }_{\text {it- } 1}+\beta_{4} \text { SIZE }_{\text {it- } 1}+\beta_{5} \text { TANG }_{\text {it- } 1}+ \\
& \beta_{6} \text { REVVOL }_{\text {it-1 }}+\beta_{7} \text { AGE }_{\text {it }}+\beta_{8} \text { PROFIT }_{\text {it-1 }}+\beta_{9} \text { OCF }_{\text {it-1 }}+\beta_{10} \text { ECONCON }_{\mathrm{t}}+ \\
& \beta_{11} \text { BSIZE }_{i t}+\beta_{12} \text { BINDEP }_{i t}+e_{i t}
\end{aligned}
$$

where $e_{i t}$ is the error term and $\beta_{j}(j=1,2, \ldots, 12)$ are the coefficients of the independent variables to be estimated.

Net operating working capital (NWC) is measured as the sum of the accounts receivables and inventories net of the value of accounts payables. Because using the net working capital value could result in a result dominated by the largest firms and heteroskedasticity, it is then scaled by the total assets as suggested by Fama and French (1998). Lagged values are used for most of the independent variables in order to alleviate issues of endogeneity that may be caused by some of the independent variables such as leverage, profitability and operating cash flow. This approach is adopted by Hill et al. (2010).

The Ordinary Least Squares (OLS) method is first used to estimate the model. However, due to the problems of heteroskedasticity and autocorrelation, which is expected in panel datasets, the estimates are recalculated with Rogers' (1993) standard errors adjusted for firm level, time and two-dimensional clustering, as recommended by Petersen (2009). The fixed effect model is also estimated although according to Petersen (2009) given the short time frame, clustered standard errors give more efficient estimates.

\section{Results and Discussion}

\section{Description of Sample}

The sample distribution and the average NWC by sector is reported in Table 1 below. However, the different average values may not be able to indicate whether significant differences exist between sectors. Hence, also presented are the results of the one-way ANOVA analysis and the Kruskal-Wallis (Kruskal \& Wallis 1952) nonparametric Kindependent test results. 
Table 1

Sampling Distribution

\begin{tabular}{lccccccc}
\hline Sector & Observations & $\begin{array}{c}\text { No of } \\
\text { Firms }\end{array}$ & $\begin{array}{c}\text { \% of } \\
\text { Firms }\end{array}$ & $\begin{array}{c}\text { Mean } \\
\text { NWC }\end{array}$ & $\begin{array}{c}\text { Median } \\
\text { NWC }\end{array}$ & ANOVA & $\begin{array}{c}\text { Kruskal- } \\
\text { Wallis Test }\end{array}$ \\
\hline Industrial Products & 504 & 63 & 32.8 & 0.186719 & 0.195702 & & \\
Properties & 272 & 34 & 17.7 & 0.020592 & 0.024106 & & \\
Consumer Products & 176 & 22 & 11.6 & 0.204977 & 0.191684 & & \\
Construction & 136 & 17 & 8.85 & 0.148841 & 0.144734 & $(0.00)^{*}$ & $(0.000)^{*}$ \\
Plantation & 112 & 14 & 7.29 & 0.031189 & 0.009156 & & \\
Trading / Services & 336 & 42 & 21.9 & 0.121651 & 0.089941 & & \\
\hline
\end{tabular}

${ }^{a}$ F-statistic, ${ }^{b}$ Chi-square statistic, ${ }^{*}$ Significance at $1 \%$ level

The results in Table 1 indicate significant differences in the size of NWC across sectors. The results support the findings of previous studies such as by Hawawini et al. (1986) which document the influence of industry on a firm's working capital investment. According to the mean NWC and the mean rank of the Kruskal-Wallis test (not shown here), the Consumer Products sector has the highest investment in NWC, followed by the Industrial Products sector. This is not surprising as most of the firms in these sectors are from the manufacturing industry, which requires high investment in working capital. The lowest mean is for the properties sector followed closely by the plantations sector. Hence, the differences across industries (or sectors) confirm the suspicion that the investment in working capital may be affected by certain industrial characteristics such as asset tangibility.

The mean, median, standard deviation, minimum and maximum values are calculated for each variable and are presented in Table 2.

Table 2

Descriptive Statistics

\begin{tabular}{lrrrrr}
\hline & Mean & Median & Std. Deviation & Minimum & Maximum \\
\hline NWC & 0.131543 & 0.118304 & 0.1727304 & -0.4083 & 0.6134 \\
LEV & 0.266090 & 0.202472 & 0.2528062 & 0 & 0.8781 \\
GROWTH & 0.042814 & 0.056353 & 0.3438257 & -1.2687 & 1.2690 \\
MTB & 0.957683 & 0.897433 & 0.3432371 & 0.3682 & 2.4171 \\
SIZE & 13.204603 & 13.061680 & 1.2439663 & 9.9757 & 17.9913 \\
TANG & 0.361808 & 0.349207 & 0.2175404 & 0.0071 & 0.9040 \\
REVVOL & 0.285363 & 0.226171 & 0.2079351 & 0.0440 & 1.1506 \\
AGE & 28.29 & 27.00 & 17.311 & 3 & 94 \\
PROFIT & 0.020093 & 0.058000 & 0.2983403 & -1.8475 & 1.0180 \\
OCF & 0.005136 & 0.061667 & 0.4134121 & -2.4637 & 1.5101 \\
BSIZE & 7.74 & 8.00 & 1.804 & 3 & 15 \\
BINDEP & 0.397656 & 0.375000 & 0.1107251 & 0.1000 & 0.8333 \\
ECONCON & 0.081409 & 0.090713 & 0.0645069 & -0.0604 & 0.1661 \\
\hline
\end{tabular}

The statistics displayed in Table 2 suggest that on average, for every Ringgit of asset held by the firm, approximately 0.13 cents is tied up in net working capital. The mean being 
0.13 indicates a relatively flexible working capital management policy. Compared to the study by Hill et al. (2010), this figure is smaller than that of US companies, which was reported to be around $22.7 \%$ of total assets. The median NWC is only slightly lower than the mean (0.118). However, there are also firms which have aggressive working capital policies as can be seen by the negative minimum value.

Before running the regression, the correlations are checked to ensure that there are no cases of multicollinearity. The Pearson correlation coefficients between all the variables, dependent and independent, and their respective p-values are provided in Table 3. According to the correlations, all the variables have low correlation values with VIFs of less than 1.3.

\section{Regression Results}

Table 4 reports the results of the regression analysis. The estimates are calculated using various techniques to achieve more robust results. The results for the static model (Equation 1) using the Ordinary Least Square (OLS) technique are shown in Column (1), while the results in Column (II) are those of the OLS regression using the Huber-White-sandwich (Huber 1967; White 1982) estimator of the variance of the regression estimator. In Column (III), (IV) and (V), the model is re-estimated using OLS technique with Roger's standard errors adjusted for clustering across firm, time and across both dimensions, respectively. Finally, column (IV) presents the results of the fixed effects model.

Given the size of the standard errors, the results from the OLS regression with standard errors adjusted for firm level clustering (Column III) produce the most unbiased standard errors. As a robustness check, when the standard errors are clustered by firm and year (Column V), the results are quite similar to that in Column III. Hence, the discussion on the effect of each variable on the net working capital investment is based on the results in Column III. 
Table 3

Pearson Correlation Coefficients

\begin{tabular}{|c|c|c|c|c|c|c|c|c|c|c|c|c|c|c|}
\hline & NWC & LEV & GROWTH & МТВ & SIZE & TANG & REVVOL & AGE & PROFIT & OCF & ECONCON & BSIZE & BINDEP & VIF \\
\hline NWC & 1 & & & & & & & & & & & & & \\
\hline LEV & $-0.228 * *$ & 1 & & & & & & & & & & & & 1.18 \\
\hline GROWTH & $0.095^{* *}$ & $-0.052 *$ & 1 & & & & & & & & & & & 1.12 \\
\hline МТВ & $-0.085^{* *}$ & $-0.110 * *$ & 0.043 & 1 & & & & & & & & & & 1.09 \\
\hline SIZE & $-0.277 * *$ & $0.273^{* *}$ & 0.045 & $0.066 * *$ & 1 & & & & & & & & & 1.28 \\
\hline TANG & $-0.114^{* *}$ & 0.015 & $0.081^{* *}$ & $0.175^{* *}$ & 0.039 & 1 & & & & & & & & 1.09 \\
\hline REVVOL & $-0.177 * *$ & $0.071^{* *}$ & $0.088^{* *}$ & $-0.062 *$ & -0.017 & $-0.149 * *$ & 1 & & & & & & & 1.12 \\
\hline AGE & $-0.210 * *$ & $0.096 * *$ & $-0.057 *$ & -0.048 & $0.282 * *$ & -0.038 & $0.106^{* *}$ & 1 & & & & & & 1.20 \\
\hline PROFIT & $0.117^{* *}$ & $-0.131^{* *}$ & $0.094^{* *}$ & $0.108^{* *}$ & -0.025 & 0.019 & $-0.060 *$ & $-0.083^{* *}$ & 1 & & & & & 1.08 \\
\hline OCF & $0.201 * *$ & $-0.184 * *$ & $0.257 * *$ & $-0.054 *$ & $0.078 * *$ & $0.121 * *$ & $-0.205^{* *}$ & $-0.085^{* *}$ & $0.216^{* *}$ & 1 & & & & 1.26 \\
\hline ECONCON & 0.011 & 0.013 & -0.044 & -0.021 & 0.018 & -0.045 & -0.012 & 0.034 & -0.048 & -0.025 & 1 & & & 1.01 \\
\hline BSIZE & 0.023 & $-0.069 * *$ & $0.082 * *$ & $0.088^{* *}$ & $0.170^{* *}$ & $0.150^{* *}$ & $-0.138^{* *}$ & $-0.141^{* *}$ & $0.092 * *$ & $0.116^{* *}$ & -0.038 & 1 & & 1.22 \\
\hline BINDEP & $-0.111^{* *}$ & $0.072^{* *}$ & 0.011 & -0.041 & $0.066^{* *}$ & 0.017 & 0.018 & $0.236^{* *}$ & -0.026 & -0.048 & 0.033 & $-0.280 * *$ & 1 & 1.15 \\
\hline
\end{tabular}

** Significant at $1 \%$ level, * Significant at $5 \%$ level 
Table 4

Effect of Dependent Variables on Working Capital Investment

\begin{tabular}{|c|c|c|c|c|c|c|c|}
\hline Independent Variable & Predicted Sign & (I) & (II) & (III) & (IV) & $(\mathrm{V})$ & (VI) \\
\hline Intercept & & $\begin{array}{c}0.7269454^{* * *} \\
(0.0487319)\end{array}$ & $\begin{array}{c}0.7269454^{* * *} \\
(0.0412525)\end{array}$ & $\begin{array}{c}0.7269454 * * * \\
(0.088632)\end{array}$ & $\begin{array}{c}0.7269454 * * * \\
(0.0489664)\end{array}$ & $\begin{array}{c}0.7269454^{* * *} \\
(0.0924748)\end{array}$ & $\begin{array}{c}0.2904417 * * * \\
(0.1062758)\end{array}$ \\
\hline LEV & - & $\begin{array}{c}-0.0778885 * * * \\
(0.0169512)\end{array}$ & $\begin{array}{c}-0.0778885 * * * \\
(0.0180723)\end{array}$ & $\begin{array}{c}-0.0778885^{* *} \\
(0.0342773)\end{array}$ & $\begin{array}{c}-0.0778885 * * * \\
(0.0152649)\end{array}$ & $\begin{array}{c}-0.0778885^{* *} \\
(0.0328837)\end{array}$ & $\begin{array}{c}-0.0697183 * * * \\
(0.0158086)\end{array}$ \\
\hline GROWTH & $+/-$ & $\begin{array}{c}0.0426799 * * * \\
(0.0121211)\end{array}$ & $\begin{array}{c}0.0426799 * * * \\
(0.0135788)\end{array}$ & $\begin{array}{c}0.0426799 * * * \\
(0.0129167)\end{array}$ & $\begin{array}{c}0.0426799 * * \\
(0.016702)\end{array}$ & $\begin{array}{c}0.0426799 * * * \\
(0.0161683)\end{array}$ & $\begin{array}{c}0.0019723 \\
(0.00679)\end{array}$ \\
\hline MTB & - & $\begin{array}{c}-0.0387264 * * * \\
(0.0120209)\end{array}$ & $\begin{array}{c}-0.0387264 * * * \\
(0.0127011)\end{array}$ & $\begin{array}{l}-0.0387264 * \\
(0.0229659)\end{array}$ & $\begin{array}{c}-0.0387264^{* *} \\
(0.0122391)\end{array}$ & $\begin{array}{l}-0.0387264 * \\
(0.0227137)\end{array}$ & $\begin{array}{r}-0.0037598 \\
(0.0106075)\end{array}$ \\
\hline SIZE & $+/-$ & $\begin{array}{c}-0.030632^{* * *} \\
(0.0035937)\end{array}$ & $\begin{array}{c}-0.030632^{* * *} \\
(0.0031524)\end{array}$ & $\begin{array}{c}-0.030632 * * * \\
(0.0067633)\end{array}$ & $\begin{array}{c}-0.030632 * * * \\
(0.0045718)\end{array}$ & $\begin{array}{c}-0.030632 * * * \\
(0.0075303)\end{array}$ & $\begin{array}{c}0.0086893 \\
(0.0074999)\end{array}$ \\
\hline TANG & $+/-$ & $\begin{array}{c}-0.1115278 * * * \\
(0.018967)\end{array}$ & $\begin{array}{c}-0.1115278 * * * \\
(0.0198776)\end{array}$ & $\begin{array}{c}-0.1115278^{* *} \\
(0.0435465)\end{array}$ & $\begin{array}{c}-0.1115278 * * * \\
(0.018442)\end{array}$ & $\begin{array}{c}-0.1115278 * * * \\
(0.0429102)\end{array}$ & $\begin{array}{c}-0.1429366^{* * * *} \\
(0.0228039)\end{array}$ \\
\hline REVVOL & $+/-$ & $\begin{array}{c}-0.1365253 * * * \\
(0.0200333)\end{array}$ & $\begin{array}{c}-0.1365253 * * * \\
(0.0224949)\end{array}$ & $\begin{array}{c}-0.1365253 * * * \\
(0.0414837)\end{array}$ & $\begin{array}{c}-0.1365253 * * * \\
(0.019143)\end{array}$ & $\begin{array}{c}-0.1365253 * * * \\
(0.039766)\end{array}$ & $\begin{array}{c}0.0095527 \\
(0.0151228)\end{array}$ \\
\hline AGE & $+/-$ & $\begin{array}{c}-0.0009522 * * * \\
(0.0002493)\end{array}$ & $\begin{array}{c}-0.0009522 * * * \\
(0.000241)\end{array}$ & $\begin{array}{c}-0.0009522 * \\
(0.0005432)\end{array}$ & $\begin{array}{c}-0.0009522 * * * \\
(0.0001589)\end{array}$ & $\begin{array}{c}-0.0009522^{*} \\
(0.0005121)\end{array}$ & $\begin{array}{c}-0.0000762 \\
(0.0011141)\end{array}$ \\
\hline PROFIT & $+/-$ & $\begin{array}{c}0.0303705^{* *} \\
(0.0137569)\end{array}$ & $\begin{array}{c}0.0303705^{*} \\
(0.0180052)\end{array}$ & $\begin{array}{c}0.0303705 \\
(0.0207422)\end{array}$ & $\begin{array}{c}0.0303705^{* *} \\
(0.0101081)\end{array}$ & $\begin{array}{c}0.0303705^{* *} \\
(0.0144301)\end{array}$ & $\begin{array}{c}0.0242313^{* * *} \\
(0.0076907)\end{array}$ \\
\hline OCF & $+/-$ & $\begin{array}{c}0.0551698 * * * \\
(0.0107117)\end{array}$ & $\begin{array}{c}0.0551698^{* * *} \\
(0.0142033)\end{array}$ & $\begin{array}{c}0.0551698 * * * \\
(0.0173349)\end{array}$ & $\begin{array}{c}0.0551698 * * \\
(0.0176179)\end{array}$ & $\begin{array}{c}0.0551698 * * * \\
(0.0202276)\end{array}$ & $\begin{array}{c}0.001761 \\
(0.0068451)\end{array}$ \\
\hline BSIZE & + & $\begin{array}{c}0.000149 \\
(0.0024107)\end{array}$ & $\begin{array}{c}0.000149 \\
(0.0021915)\end{array}$ & $\begin{array}{c}0.000149 \\
(0.0044992)\end{array}$ & $\begin{array}{c}0.000149 \\
(0.0019896)\end{array}$ & $\begin{array}{c}0.000149 \\
(0.0044044)\end{array}$ & $\begin{array}{c}-0.0076126 * * * \\
(0.0022805)\end{array}$ \\
\hline BINDEP & $+/-$ & $\begin{array}{c}-0.0890014 * * \\
(0.0381917)\end{array}$ & $\begin{array}{c}-0.0890014 * * \\
(0.0387863)\end{array}$ & $\begin{array}{c}-0.0890014 \\
(0.0677584)\end{array}$ & $\begin{array}{c}-0.0890014 * * * \\
(0.0185296)\end{array}$ & $\begin{array}{l}-0.0890014 \\
(0.0585677)\end{array}$ & $\begin{array}{c}-0.0663494^{* *} \\
(0.0308839)\end{array}$ \\
\hline ECONCON & $+/-$ & $\begin{array}{c}0.057235 \\
(0.0613852)\end{array}$ & $\begin{array}{c}0.057235 \\
(0.060433)\end{array}$ & $\begin{array}{l}0.057235 * * \\
(0.0263901)\end{array}$ & $\begin{array}{l}0.057235^{* *} \\
(0.0194839)\end{array}$ & $\begin{array}{c}0.057235 \\
-\end{array}$ & $\begin{array}{c}0.0110241 \\
(0.0333041)\end{array}$ \\
\hline R-squared & & 0.2061 & 0.2061 & 0.2061 & 0.2061 & 0.2061 & 0.0236 \\
\hline Number of observations & & 1536 & 1536 & 1536 & 1536 & 1536 & 1536 \\
\hline
\end{tabular}

Note: Standard errors are in parenthesis, $* * *$ Significant at $1 \%$ level, $* *$ Significant at $5 \%$ level, $*$ Significant at $10 \%$ leve 


\section{Discussion of Results}

The results show that all variables except for profitability, board size and board independence are significant in influencing a firm's investment in working capital, although age and the level of information asymmetry (MTB) are significant only at the $10 \%$ level. Leverage, tangibility and GDP growth are significant at the 5\% level while growth, size, revenue volatility and size of operating cash flows are highly significant at the $1 \%$ level.

The significantly negative relationship between leverage and working capital is consistent with the pecking order theory. According to the pecking order theory, only when a firm does not have enough internal financing would it go for the next safest source of financing which is debt financing. Increase in debt means debt repayments have to be made resulting in less capital available to carry out daily operations and for future investment purposes, forcing firms to manage their working capital more efficiently, hence, reducing investment in working capital. Also, since the cost of debt financing is higher compared to the return gained from investing in liquidity, a highly levered firm will invest less of its capital in its working capital cycle (Banos-Caballero et al. 2010a). The result is consistent with Afza and Nazir (2009), Banos-Caballero et al. (2010a), Chiou et al. (2006), Erasmus (2010), Mathuva (2009), Raheman and Nasr (2007) and Zariyawati et al. (2009).

Consistent with the result of leverage is that of asymmetric information, as proxied by market to book ratio. Firms with high levels of information asymmetry would tend to use debt as a signalling device to convey information about the future of the firm, hence increasing its leverage. As per the relationship found between leverage and working capital investment, because higher leverage results in lower investment in working capital, a firm with high levels of information asymmetry will have lower investment in working capital, hence the significantly negative relationship between market to book ratio and working capital investment.

Higher asymmetric information could be due to higher investment in intangible assets. Banos-Caballero et al. (2010a) expect that firms with more tangible assets will have lower information asymmetry, resulting in lower cost of financing and hence, may have higher investment in working capital. However, they find a negative relationship between asset tangibility and working capital investment which was consistent with the findings of Fazzari and Petersen (1993). This study also finds this negative relationship, confirming the argument by Banos-Caballero et al. (2010a) that the investments compete with each other for the limited funds available and given the preference for higher returns, the investment in working capital loses out to long-term investment.

While leverage is an indication of financial risk faced by a company, revenue volatility indicates the operating risk. Similar to the result of leverage, revenue volatility has a negative impact on working capital investment. This result is consistent with that found by Hill et al. (2010), who argue that with greater sales volatility, managers react by being more aggressive in their working capital management, hence investing less in the working capital cycle. The firm would then rely more on its payables rather than its receivables (Deloof \& Jergers 1999; Ng et al. 1999).

On the other hand, if the firm is experiencing growth in sales in the previous year, it could be stocking up on its inventory in anticipation of future sales growth, which could outweigh the effect of sales growth on trade credit, thus increasing investment in working capital. Also, sales growth could be stimulated through the granting of credit to customers resulting in higher receivables, thus again increasing the working capital cycle. Hence, prior year sales growth can result in higher investment in operating working capital as is found in this study. This relationship is consistent with the findings of Appuhami (2008), Chiou et al. (2006), Moussawi et al. (2006), Nazir and Afza (2009). 
Younger firms grow at a faster pace compared to more mature firms which have a more stable growth. Since sales growth is found to influence investment in working capital positively, then age will have a negative impact on working capital investment, which is what is found in this study. Hence, younger firms will invest more in their working capital cycle so that the growth in sales can be sustained.

Aside from sales growth, another indicator of well-being of a firm is its operating performance. Both profitability and operating cash flow are found to exert a significant positive influence on working capital investment. However, profitability is found to be insignificant, while operating cash flow is highly significant in influencing working capital investment. This is true since a firm would have more cash available due to the operating cash flows, hence not requiring it to squeeze as much out from its working capital cycle. The relationship found is consistent with that of Chiou et al. (2006), Hill et al. (2010) and Nazir and Afza (2008) and is contrary to the results of Appuhami (2008) and Banos-Caballero et al. (2010a).

The negative relationship between size of a firm and working capital investment may be because larger firms are better at managing their cash cycles as is shown by Moss and Stein (1993). Or it may be as argued by Moussawi et al. (2006) that when a firm is large, it is able to reduce its investment in working capital due to its good relationship with its suppliers. The result is consistent with the studies by Moss and Stein (1993), Chiou et al. (2006) and Nazir and Afza (2008). However, it is contrary to those of Banos-Caballero et al. (2010a), Hill et al. (2010) and Moussawi et al. (2006).

Moussawi et al. (2006) find significant relationships between the board characteristics and working capital investment. In this study, however, for both board characteristics, insignificant relationships are found. Zariyawati et al. (2010) too find insignificant relationships between these two variables and working capital for the Malaysian case. The signs of the variables are as expected, i.e. large and less independent boards are found to have higher net operating working capital. An insignificant relationship could mean that working capital management issues may not be of importance to Board of Directors and so decisions made by Board of Directors do not influence the working capital investment of their firms.

A non-firm specific variable considered also is the impact of economic conditions. The negative relationship predicted by Banos-Caballero et al. (2010a) is confirmed by the results of this study. Economic condition is found to be highly significant in affecting working capital investment. Abundance of funds during economic boom periods will not be a cause for worry and firms will thus not be too concerned about their level of working capital, but during recession periods, as much money as possible needs to be squeezed out and the easiest way is through working capital improvements.

\section{Conclusion}

The unsatisfactory working capital performance of firms in Malaysia over the past few years raises the question on why this is so. Hence, the objective of this study is to understand the determinants of working capital investment of firms in Malaysia. Using data from 192 companies over a period of 8 years (from year 2000 to 2007), the relationship of firm and board characteristics with investment in net operating working capital is studied. The results of the multiple regression analysis provide this conclusion. In times of economic expansion/boom, younger and smaller firms with less tangible assets, low leverage, high sales growth, high operating cash flows (and profitability), less volatile revenues and low levels of asymmetric information are likely to have the highest investments in operating working capital. During times of economic downturn, the same firm will try to lower its working capital investment. Board characteristics, namely, size of board and the independence of the 
board are found to have insignificant influence on the investment in operating working capital made by firms.

This study contributes to the scarce but growing literature on the determinants of working capital management, an area that has not been given the attention it needs. The results would be helpful to investors in evaluating the working capital strategy of firms as it may be able to give some indication about the financial wellbeing of the firm. It is found that different firm characteristics make it necessary for firms to have different working capital policies which are much more suited to their situation. In fact, the non-parametric tests also indicate the presence of a sectoral/industrial effect that cannot be ignored. Hence, a better understanding of why firms adopt a specific working capital policy will allow financial institutions to determine whether the firms are justified in adopting a specific policy, and in evaluating their financial wellbeing.

However, from the regression results it is seen that the R-squared is very low and the constant term is highly significant. Although low R-squared is common in most studies on working capital and cash management, it is obvious that there may be other factors which may influence working capital investment policy. Further study on other firm specific or even strategic determinants is warranted. Also, there may be differences in the working capital investment policies in countries with different financial systems, for instance, countries with a bank-based financial system as compared to those with a market-based financial system. This study examines the determinants of a firm's working capital investment policy but equally, or maybe more, important is the consequences of the policy especially on firm valuation. While many studies have been conducted on the effect of working capital management/investment on profitability, not much has been done on firm value. Hence a study on the impact of working capital investment policy on firm value is needed especially given the scarce literature on this issue.

\section{References}

Appuhami, BAR 2008, 'The impact of firms' capital expenditure on working capital management: An empirical study across industries in Thailand', International Management Review, vol.4, no.1, pp8-21.

Banos-Caballero, S, Garcı'a-Teruel, PJ \& Martı'nez-Solano, P 2010a, 'Working capital management in SMEs', Accounting and Finance, vol.50, pp511-527. http://dx.doi.org/10.1111/j.1467-629X.2009.00331.x

Banos-Caballero, S, Garc1'a-Teruel, PJ \& Martı'nez-Solano, P 2010b, 'How do market imperfections affect working capital management', Working Paper, Instituto Valenciano de Investigaciones Económicas, S.A., Spain, January 2010.

Bates, TW, Kahle, KM \& Stulz, RM 2009, 'Why do U.S. firms hold so much more cash than they used to?' The Journal of Finance, vol.64, no.5, pp1985-2021.

http://dx.doi.org/10.1111/j.1540-6261.2009.01492.x

Beaumont, SM \& Begemann, E 1997, 'Measuring associations between working capital and return on investment', South African Journal of Business Management, vol.28, no.1, pp1-5.

Berk, J, DeMarzo, P \& Harford, J 2009, Fundamentals of Corporate Finance, Pearson Education Inc, Boston. 
Bhattacharyya, SK \& Raghavacahari, M 1977, 'Determinants of effective working capital management - A discriminant analysis approach', Working Paper, Indian Institute of Management, March 1977.

Blazenko, G \& Vandezande, K 2003, 'Corporate holdings of finished goods inventories', Journal of Economics and Business, vol.55, pp255-266. http://dx.doi.org/10.1016/S0148-6195(03)00023-7

Brennan, M. \& Hughes, P. 1991, 'Stock prices and the supply of information', Journal of Finance, vol.46, pp1665-1691. http://dx.doi.org/10.1111/j.1540-6261.1991.tb04639.x

Brigham, EF \& Daves, PR 2004, Intermediate Financial Management, 8th edn, Thomson South-Western.

Chiou, J-R, Cheng, L \& Wu, H-W 2006, 'The determinants of working capital management', Journal of American Academy of Business, vol.10, no.1, pp149-155.

Cohen, L, Frazzini, A \& Malloy, C 2009, 'Hiring cheerleaders: Board appointments of "independent" directors', in European Finance Association: 36th Annual Meeting, Bergen, Norway, 19 - 22 August 2010, European Finance Association.

Cornforth, C 2002, 'Making sense of co-operative governance: Competing models and tensions', Review of International Co-operation, vol.95, no.1, pp51-57.

D'Mello, R, Krishnaswami, S \& Larkin, PJ 2008, 'Determinants of corporate cash holdings: Evidence from spin-offs', Journal of Banking and Finance, vol.32, pp1209-1220. http://dx.doi.org/10.1016/j.jbankfin.2007.10.005

Deloof, M 2003, 'Does working capital management affect profitability of Belgian firms?', Journal of Business Finance and Accounting, vol.30, no.3 \& 4, pp573-587. http://dx.doi.org/10.1111/1468-5957.00008

Deloof, M \& Jegers, M 1996, 'Trade credit, product quality, and intragroup trade: Some European evidence', Financial Management, vol.25, pp33-43. http://dx.doi.org/10.2307/3665806

Drobetz, W, Gruninger, MC \& Hirschvogl, S 2010, 'Information asymmetry and the value of cash’, Journal of Banking and Finance, vol.34, pp2168-2184. http://dx.doi.org/10.1016/j.jbankfin.2010.02.002

Emery, G 1987, 'An optimal financial response to variable demand', Journal of Financial and Quantitative Analysis, vol.22, pp209-225. http://dx.doi.org/10.2307/2330713

Erasmus, PD. 2010, 'The relationship between working capital management and profitability for South African listed industrial firms', The Business Review, Cambridge, vol.15, no.1, pp193-198.

Ernst \& Young 2011, All tied up: Working capital management report 2011, accessed 3 October 2011, http://www.ey.com/GL/en/Services/Transactions/All-tied-up--Working-capital-management-report-2011

Fama, EF \& French, KR 1998, 'Taxes, financing decisions, and firm value', Journal of Finance, vol.53, no.3, pp819-843. http://dx.doi.org/10.1111/0022-1082.00036

Fazzari, SM \& Petersen, B 1993, 'Working capital and fixed investment: new evidence on financing constraints', Rand Journal of Economics, vol.24, pp328-342. http://dx.doi.org/10.2307/2555961

Ferreira, MA \& Vilela, AS 2004, 'Why do firms hold cash? Evidence from EMU countries', European Financial Management, vol.10, no.2, pp295-319. 
http://dx.doi.org/10.1111/j.1354-7798.2004.00251.x

Garcia-Teruel, PJ \& Martinez-Solano, P 2007, 'Effects of working capital management on SME profitability', International Journal of Managerial Finance, vol.3, no.2, pp164. http://dx.doi.org/10.1108/17439130710738718

Ghosh, SK \& Maji, SG 2004, 'Working capital management efficiency: A study on the Indian cement industry', Management Accountant, vol.39, no.5, pp363-372.

Hawawini, G, Viallet, C \& Vora, A 1986, 'Industry influence on corporate working capital decisions', Sloan Management Review, vol.27, no.4, pp15-24.

Hill, MD, Kelly, GW \& Highfield, MJ 2010, 'Net operating working capital behavior: A first look', Financial Management, vol.39, no.2, pp783-805.

http://dx.doi.org/10.1111/j.1755-053X.2010.01092.x

Huber, PJ 1967, 'The behavior of maximum likelihood estimates under non-standard conditions', in Fifth Berkeley Symposium in Mathematical Statistics and Probability, Berkeley, CA, June 21-July 18, 1965 and December 27, 1965-January 7, 1966, University of California Press, vol.1, pp221-233.

Jensen, M 1986, 'Agency costs of free cash flow, corporate finance and takeovers', American Economic Review, vol.76, pp323-329.

Kargar, J \& Blumenthal, RA 1994, 'Leverage impact on working capital in small businesses', TMA Journal, vol.14, no.6, pp46-51.

Lamberson, M 1995, 'Changes in working capital of small firms in relation to changes in economic activity’, Mid-American Journal of Business, vol.10, no.2, pp45-50. http://dx.doi.org/10.1108/19355181199500015

Kruskal, W \& Wallis, WA 1952, 'Use of ranks in one-criterion variance analysis', Journal of the American Statistical Association, vol.47, no.260, pp583-621. http://dx.doi.org/10.1080/01621459.1952.10483441

Mathuva, DM 2009, 'Influence of working capital management components on corporate profitability: A survey on Kenyan listed firms', Research Journal of Business Management, vol.3, pp1-11.

McGuigan, JR, Moyer, RC, Rao, R \& Kretlow, WJ 2012, Contemporary Corporate Finance, 12th edn, Cengage Learning, South-Western.

Moss, JD. \& Stein, B 1993, 'Cash conversion cycle and firm size', Managerial Finance, vol.19, no.8, pp25-34. http://dx.doi.org/10.1108/eb013739

Moussawi, R, LaPlante, M, Kieschnick, R \& Baranchuk, N 2006, 'Corporate working capital management: Determinants and consequences’, Working Paper, Baylor University, November 2006.

Myers, SC 1984, 'The capital structure puzzle', Journal of Finance, vol.39, pp572-592. http://dx.doi.org/10.1111/j.1540-6261.1984.tb03646.x

Narware, PC 2004, 'Working capital and profitability-An empirical analysis', Management Accountant, vol.39, no.6, pp491-493.

Nazir, MS \& Afza, T 2009, 'Impact of aggressive working capital management policy on firms’ profitability', The IUP Journal of Applied Finance, vol.15, no.8, pp19-30.

Ng, C, Smith, J.\& Smith, R 1999, 'Evidence on the determinants of credit terms used in interfirm trade’, Journal of Finance, vol.54, no.1, pp1109-1129.

http://dx.doi.org/10.1111/0022-1082.00138 
Opler, T, Pinkowitz, L, Stulz, R \& Williamson, R 1999, 'The determinants and implications of corporate cash holdings', Journal of Financial Economics, vol.52, no.1, pp3-46. http://dx.doi.org/10.1016/S0304-405X(99)00003-3

Petersen, MA 2009, 'Estimating standard errors in finance panel data sets: Comparing approaches', The Review of Financial Studies, vol.22, no.1, pp435-634. http://dx.doi.org/10.1093/rfs/hhn053

Pinkowitz, L 2000, 'The market for corporate control and corporate cash holdings', Working Paper, Georgetown University, January 2000.

Raheman, A \& Nasr, M 2007, 'Working capital management and profitability - Case of Pakistani firms', International Review of Business Research Papers, vol.3, no.1, pp279-300.

Rogers, W 1993, 'Regression standard errors in clustered samples', Stata Technical Bulletin, vol.13, pp19-23.

Ross, SA, Westerfield, RW, Jaffe, J \& Jordan, BD 2008, Modern Financial Management, 8th edn, McGraw-Hill, New York.

Salek, JG 2005, Accounts Receivable Management Best Practices, John Wiley \& Sons, New Jersey.

Shin, HH \& Soenen, L 1998, 'Efficiency of working capital management and corporate profitability’, Financial Practice and Education, vol.8, no.2, pp37-45.

Shyam-Sunder, L \& Myers, SC 1999, 'Testing static tradeoff against pecking order models of capital structure', Journal of Financial Economics, vol.51, pp187-221.

Soenen, LA 1993, 'Cash conversion cycle and corporate profitability', Journal of Cash Management, vol.13, no.4, pp53-57.

Talha, M., Christopher, S. B. \& Kamalavalli, A. L. 2010, 'Sensitivity of profitability to working capital management: a study of Indian corporate hospitals', International Journal of Managerial and Financial Accounting, vol.2, no.3, pp213-227. http://dx.doi.org/10.1504/IJMFA.2010.034115

Vijayakumar, A., \& Venkatachalam, A. 1996, 'Responsiveness of Working Capital Management-A Case Study of Tamilnadu Sugar Corporation’, Finance India, vol.10, no.3, pp647-655.

White, H. 1982, 'Maximum likelihood estimation of misspecified models', Econometrica, vol.50, pp1-25. http://dx.doi.org/10.2307/1912526

Zariyawati, M. A., Annuar, M. N., Taufiq, H. \& Rahim, A. S. A. 2009, 'Working capital management and corporate performance: Case of Malaysia', Journal of Modern Accounting and Auditing, vol.5, no.11, pp47-54.

Zariyawati, M. A., Taufiq, H., Annuar, M. N. \& Sazali, A. 2010, 'Determinants of Working Capital Management: Evidence from Malaysia', in Financial Theory and Engineering: Proceedings of the 2010 International Conference, Dubai, UAE, 18 20 June 2010, IEEE Computer Society Press, pp. 190-194. 
AABFJ | Volume 7, no. 2, 2013 